\title{
Early Ontogeny, Growth and Mortality of Common Carp (Cyprinus carpio) at Low Concentrations of Dimethyl Sulfoxide
}

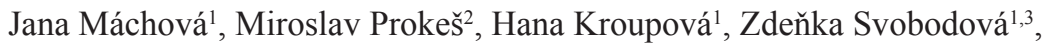 \\ Stanislava Mácová ${ }^{3}$, Petra Doleželová ${ }^{3}$, Josef Velíšek ${ }^{1}$ \\ ${ }^{1}$ University of South Bohemia, České Budějovice, Research Institute of Fish Culture and Hydrobiology, \\ Vodn̆any, Czech Republic \\ ${ }^{2}$ Institute of Vertebrate Biology Academy of Sciences of the Czech Republic, v.v.i., Brno, Czech Republic \\ ${ }^{3}$ University of Veterinary and Pharmaceutical Sciences, Brno, Czech Republic \\ Received November 10, 2008 \\ Accepted March 9, 2009
}

\begin{abstract}
Dimethyl sulphoxide (DMSO) is an important polar aprotic solvent, less toxic than other members of this class. Because of its excellent solvating power, DMSO is frequently used as solvent for chemical reactions involving salts, especially Finkelstein reactions and other nucleophilic substitutions. Furthermore, DMSO is used as auxiliary substance in toxicity tests on aquatic organisms, usually at concentrations of 0.2 and $0.5 \mathrm{ml} \cdot \mathrm{l}^{-1}$. The aim of the present study was to evaluate the effect of DMSO on early development, growth and mortality of early life stages in common carp. Tests were performed from fertilized egg to the end of the larval period with continuous exposure to DMSO at concentrations of $0.2,0.5,1.0$ and $5.0 \mathrm{ml} \cdot \mathrm{l}^{-1}$. Mortality of embryos and larvae, intensity of development and growth, weight and occurrence of abnormalities were analyzed. DMSO exposure at all the tested concentrations did not result in any lethal effects or abnormalities compared to the control over the entire test period (29 days). Growth indicators were similar in DMSO treated (at concentrations of $0.2,0.5$ and $1.0 \mathrm{ml} \cdot \mathrm{l}^{-1}$ ) and control groups. However, mean body weight $(35 \pm 9 \mathrm{mg})$ of larvae exposed to the highest DMSO concentration $\left(5 \mathrm{ml} \cdot \mathrm{l}^{-1}\right)$ tested was significantly lower compared to the control $(45 \pm 14 \mathrm{mg})$.
\end{abstract}

DMSO, auxiliary substance, toxicity, fish embryos and larvae

Aquatic toxicology tests are designed for readily water soluble substances. However, due to the occurrence of several water-insoluble substances, the use of various solvents is needed. A major concern in toxicology studies is the choice of appropriate solvents. Carrier solvents may also have toxic effects on organisms (Hallare et al. 2006; Ball 1966; Rayburn and Fisher 1997; Benville 1968). Hence, it was necessary to set guidelines that will describe the types and the maximum allowable concentrations of the solvent to be used in experimental systems that will cause no significant impact on the observed results (Hallare et al. 2006).

Dimethyl sulphoxide (DMSO) is commonly used in fish toxicity tests as a solvent for several water-insoluble substances (Rufli et al. 1998; Rayburn et al. 1991). DMSO is a colourless hygroscopic liquid that is synthesized by the oxidation of dimethyl sulphide, or originates as a waste product from wood pulp processing. Its chemical structure creates extraordinary properties. The sulphur-oxygen bond determines the polar nature of DMSO with the capability to dissolve sparingly soluble substances, and it is completely miscible in water, common organic solvents and unsaturated hydrocarbons (Willhite and Katz 1984). Furthermore, the chemical structure of DMSO enables it to penetrate membrane barriers by increasing the permeability without affecting the morphologic characteristics of the skin and body membranes. Therefore, DMSO acts as a skin penetration enhancer for drugs and other substances (Kligman 1965a; Kligman 1965b; Jacob et al. 1964; Stoughton and Fritsch 1964). The main applications and properties of DMSO were summarized in reviews by Yu and Quinn (1994) and Hutchinson et al. (2006).

Address for correspondence:

Ing. Jana Máchová

University of South Bohemia České Budějovice

Research Institute of Fish Culture and Hydrobiology

38925 Vodňany, Czech Republic
Phone: +420387774618

Fax: +420383382396

E-mail:machova@vurh.jcu.cz

http://www.vfu.cz/acta-vet/actavet.htm 
Because of its excellent properties it is also used as a cryoprotectant in cryopreservation of fish and invertebrate embryos (Cabrita et al. 2003). Most cryoprotectants have a toxic effect on cells to a certain extent. With DMSO known to be harmful to some cells, it was important to determine the optimum intracellular concentration of cryoprotectant (Suzuki et al. 1995). Also, as some studies showed that cryoprotectant toxicity is species-dependent (Cabrita et al. 2006), the toxicity of DMSO has been evaluated on different species of water organisms (Rayburn and Fisher 1997; Chao et al. 1994; Pillai et al. 2001; Ding et al. 2007; Lahnsteiner 2008). On the other hand, DMSO has already been reported to be inappropriate as a solvent in an in vitro study due to its genotoxicity (Herbold et al. 1998).

The current study aimed to assess the effect of low concentrations of DMSO on mortality, growth and early ontogeny of common carp, and to evaluate the suitability of this substance for use in tests at the early life stage of this fish species.

\section{Materials and Methods}

Test substance

The chemical compound DMSO (dimethyl sulphoxide for SP spectroscopy uvasol), with a purity $\geq 99.8 \%$, was purchased from Merck KGaA (Germany).

Dilution water

The dilution water used was aerated tap water with the following quality indicators: dissolved oxygen $>60 \%$, temperature $19-22{ }^{\circ} \mathrm{C}$, ANC4.5 (acid neutralization capacity): $1.15 \mathrm{mmol} \cdot \mathrm{l}^{-1} \mathrm{CODMn}$ (chemical oxygen demand): $1.5 \mathrm{mg} \cdot l^{-1}$, total ammonia: $0.04 \mathrm{mg} \cdot l^{-1} \mathrm{~N}-\left(\mathrm{NH}_{4}^{+}+\mathrm{NH}_{3}\right)$, sum of $\mathrm{Ca}^{2+}+\mathrm{Mg}^{2+}: 14 \mathrm{mg} \cdot \mathrm{l}^{-1}$.

Test organisms

For embryo-larval tests on common carp, embryos from the breeding operations of the Dept. of Fish Genetics and Breeding of the Research Institute of Fish Culture and Hydrobiology at University of South Bohemia in Vodňany were used. Fish were reproduced according to standard methods of artificial reproduction as described by Kocour et al. (2005).

Embryo-larval test on common carp (Cyprinus carpio)

The procedure was based on the OECD 210 Guideline for Testing of Chemicals (Fish, Early-Life Stage Toxicity Test). At $24 \mathrm{~h}$ post-fertilization, unfertilized eggs were discarded, and 100 eggs were randomly transferred into each of 15 crystallization basins containing $700 \mathrm{ml}$ of the appropriate test solution. Triplicate groups of $100 \mathrm{fish}$ for each of six test conditions were used as follows:

DMSO concentrations:

Group 1: $0.2 \mathrm{ml} \cdot \mathrm{l}^{-1}$

Group 2: $0.5 \mathrm{ml} \cdot 1^{-1}$

Group 3: $1.0 \mathrm{ml} \cdot 1^{-1}$

Group 4: $5.0 \mathrm{ml} \cdot \mathrm{l}^{-1}$

Group C: control group, tap water without DMSO

Test baths were gently aerated at a constant rate, and $\mathrm{pH}$, water temperature and water oxygen saturation were monitored on a daily basis.

After swim-up and yolk resorption, the larvae were fed ad libitum twice daily with freshly hatched Artemia salina. Observations and bath changes were made twice daily after feeding, and dead larvae recorded and removed. Mortality rate was monitored, with cumulative mortality and survival rates calculated. During and at the end of the test (T5, T15, T21 and T29 [T = time of the test, number = age of fish in days], T0 = fertilization of eggs) samples of embryos and larvae were collected and fixed in $4 \%$ formaldehyde. Total test duration was 29 days when the majority of fish from the control group had reached the last larval step (L6).

Sampled organisms were examined to monitor their early ontogeny, the occurrence of morphological abnormalities (malformations), intensity of longitudinal and weight growth, and Fulton's weight condition factor (FWC). Length of organisms was measured under a stereomicroscope (Olympus SZ61/SZ51) using a micrometer (an accuracy of $0.01 \mathrm{~mm}$ ), and weight by using lab balances Mettler (an accuracy of $0.1 \mathrm{mg}$ ). All indicators were measured individually.

Growth rate evaluation

The mean specific growth rate (SGR) for fish in each of the experimental groups was calculated for the period of time beginning with T5 (the first sampling time) and ending with T29 (end of the experiment). The following equation was used:

$S G R=\frac{\overline{\ln w_{2}}-\overline{\ln w_{1}}}{t_{2}-t_{1}} \cdot 100$ 
SGR $=$ average specific growth rate in the group $\left(\% \cdot \mathrm{d}^{-1}\right), \mathrm{w}_{1}=$ weight of particular fish at time $\mathrm{t}_{1}(\mathrm{mg}), \mathrm{w}_{2}=\mathrm{weight}$ of particular fish at time $t_{2}(\mathrm{mg}), \overline{\ln \mathrm{w}_{1}}=$ average of the natural logarithms of the $\mathrm{w}_{1}$ values, $\frac{\ln \mathrm{w}_{2}}{=}=$ average of the natural logarithms of the $\mathrm{w}_{2}$ values, $\mathrm{t}_{1}=$ time (days) at the first sampling time, $\mathrm{t}_{2}=$ time (days) at the end of exposure, $\mathrm{d}=$ day.

The inhibition of specific growth rate in each experimental group was calculated as follows:

$I_{x}[\%]=\frac{S G R_{\mathrm{c}} \text { (control) }-S G R_{x} \text { (group) }}{S G R_{\mathrm{c}}(\text { control })} \cdot 100$

$I_{\mathrm{x}}=$ inhibition of average specific growth in the selected experimental group after $x$ days of exposure, $S G R_{c}=$ average specific growth rate in the control group, $S G R_{x}$ (group) = mean specific growth rate in the selected experimental group.

Test schedule

T0: fertilization of eggs; T4: start of hatching; T6: hatching completed; T7: start of exogenous (Artemia salina) feeding; T29: end of the test.

Characteristics of developmental periods

Determination of developmental periods and steps followed Peňáz et al. (1983), who divided early fish ontogeny into nine embryonic (E1-E9), six larval (L1-L6) and two juvenile steps (J1-J2).

\section{Statistical analysis}

The statistical software program STATISTICA (version 7.1 for Windows, StatSoft) was used to compare differences among test groups. Prior to analysis, all measured variables were evaluated for normality (KolmogorovSmirnov test) and homoskedasticity of variance (Bartlett's test). If these conditions were satisfied, a one-way ANOVA was employed to determine whether there were significant differences in measured variables among experimental groups. When a difference was detected $(p<0.05)$, Dunnett's multiple range test was applied. If conditions for ANOVA were not satisfied, a non-parametric test (Kruskal-Wallis) was used (Zar 1996).

\section{Hatching}

\section{Results}

Embryos began to hatch on T4, and in the next $24 \mathrm{~h}$ (T5) most embryos in the control and in all experimental groups were hatched. No significantly negative effects of DMSO at the concentrations tested on hatching and viability of embryos were found.

\section{Cumulative mortality}

Cumulative mortality of common carp samples exposed to DMSO and the control sample was between 12-18\% (Fig. 1). DMSO in the tested concentrations had no negative influence on the early-life stages of common carp mortality.

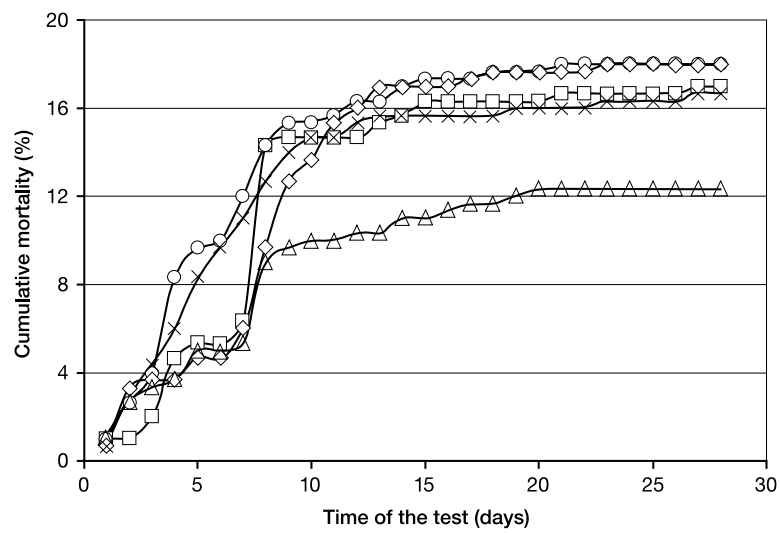

$\neg-$ control - - group $1 \multimap$ group $2 \rightarrow$ group $3 \quad \triangle$ group 4

Fig. 1. Cumulative mortality (\%) of common carp individuals (embryos and larvae) during the embryo-larval test. Explanations: time $(\mathrm{d})=$ number of days after the fertilization of eggs 
Length and weight growth indicators

The time course of weight (mg), total length (mm), and FWC of the fish embryos and larvae in relation to DMSO concentration in water are depicted in Table 1 and Figs 2, 3 and 4, respectively. At the beginning of the test (T5) a significant increase $(p \leq 0.05)$ of $13 \%$ in the average weight of larvae exposed to $5 \mathrm{ml} \cdot \mathrm{l}^{-1}$ DMSO compared to the control was observed. However, in the following period, a decrease in weight and length of these larvae was found compared to the control. On the $15^{\text {th }}$ day of the test, fish exposed to $5 \mathrm{ml} \cdot 1^{-1} \mathrm{DMSO}$ had a $13 \%$ lower $(p \leq 0.05)$ mean weight compared to the control. In the next sampling time (T21), the difference was $16 \%$, and at the end of the test $21 \%(p \leq 0.01)$. The differences between the length of fish exposed to $5 \mathrm{ml} \cdot \mathrm{l}^{-1}$ and the control remained at $5 \%$ till the end of the test. No significant negative effects of DMSO on longitudinal and weight growth of the common carp embryos and larvae were detected at the lower concentration tested.

Table 1. Growth rate and fish mortality results of the 29 day embryo-larval test on common carp

\begin{tabular}{|l|c|c|c|c|c|}
\hline Fish Group & Control & 1 & 2 & 3 & 4 \\
\hline DMSO $\left(\mathrm{ml} \cdot \cdot^{-1}\right)$ & 0 & 0.2 & 0.5 & 1.0 & 5.0 \\
\hline $\mathrm{W}_{5}($ mean $\pm \mathrm{SD}, \mathrm{mg})$ & $1.22 \pm 0.18$ & $1.26 \pm 0.15$ & $1.15 \pm 0.13$ & $1.3 \pm 0.16$ & $1.42 \pm 0.26$ \\
\hline $\mathrm{W}_{29}($ mean $\pm \mathrm{SD}, \mathrm{mg})$ & $44.92 \pm 14.04$ & $50.14 \pm 12.66$ & $46.47 \pm 11.54$ & $45.98 \pm 14.40$ & $35.49 \pm 8.79$ \\
\hline SGR & 15.5 & 15.9 & 15.9 & 15.3 & 13.9 \\
\hline $\mathrm{I}(\%)$ & - & -3 & -0.2 & 4 & 9 \\
\hline Total mortality $(\%)$ & 17 & 18 & 18 & 17 & 12 \\
\hline
\end{tabular}

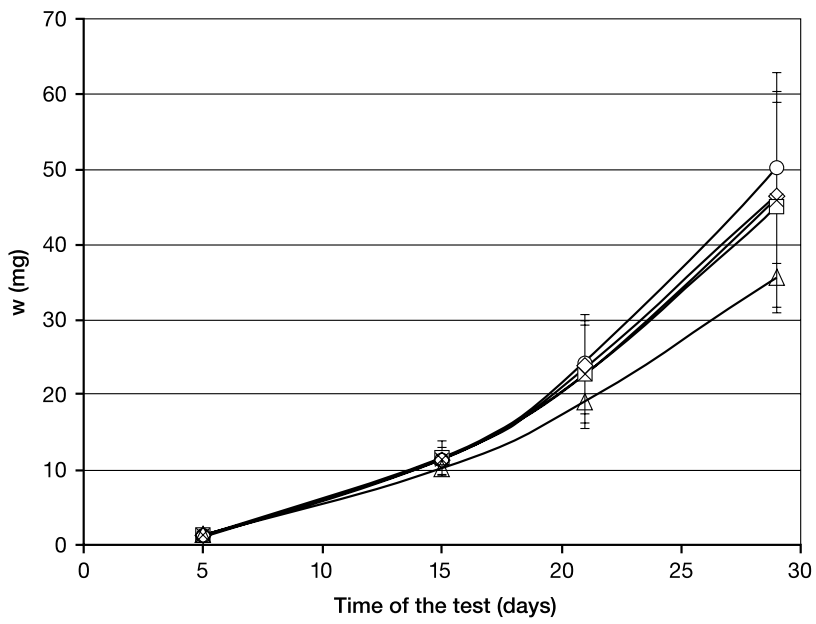

$\neg-$ control - -group $1 \multimap$ group $2 \rightarrow$ group $3 \multimap$ group 4

Fig. 2. Mean weight $( \pm \mathrm{SD})$ of common carp embryos and larvae throughout the embryo-larval test. Explanations: time $(\mathrm{d})=$ number of days after the fertilization of eggs

Early ontogeny and occurrence of morphological abnormalities

No significant differences $(p \leq 0.05)$ in early ontogeny of carp embryos and larvae were noticed among test groups. Early ontogeny indicators of all tested groups were comparable to the control (Table 2).

Furthermore, no significant differences in the type and occurrence of morphological abnormalities were observed in tested fish embryos and larvae during the test. 


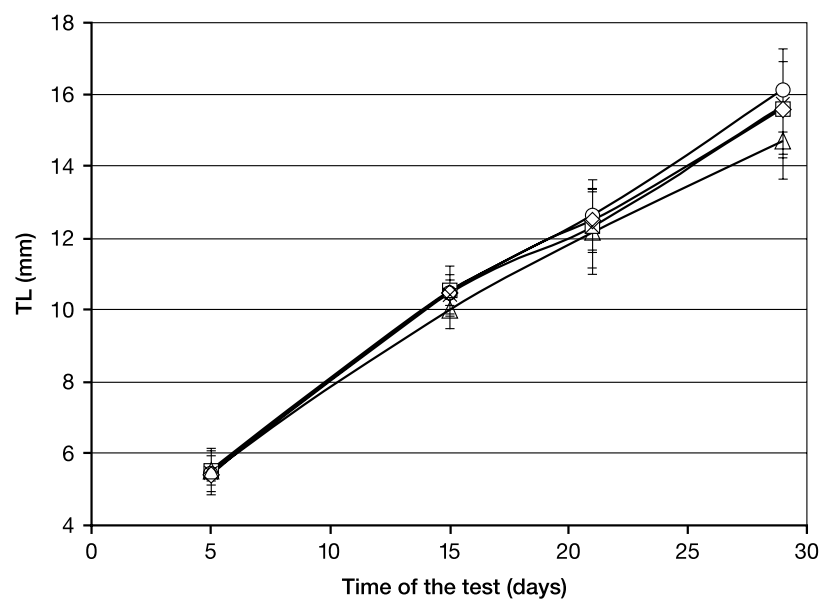

$\neg-$ control $\multimap$-group $1 \multimap$ group $2 \rightarrow$ group $3 \multimap$ group 4

Fig. 3. Longitudinal growth of common carp embryos and larvae throughout the embryo-larval test. Explanations: time $(d)=$ number of days after the fertilization of eggs

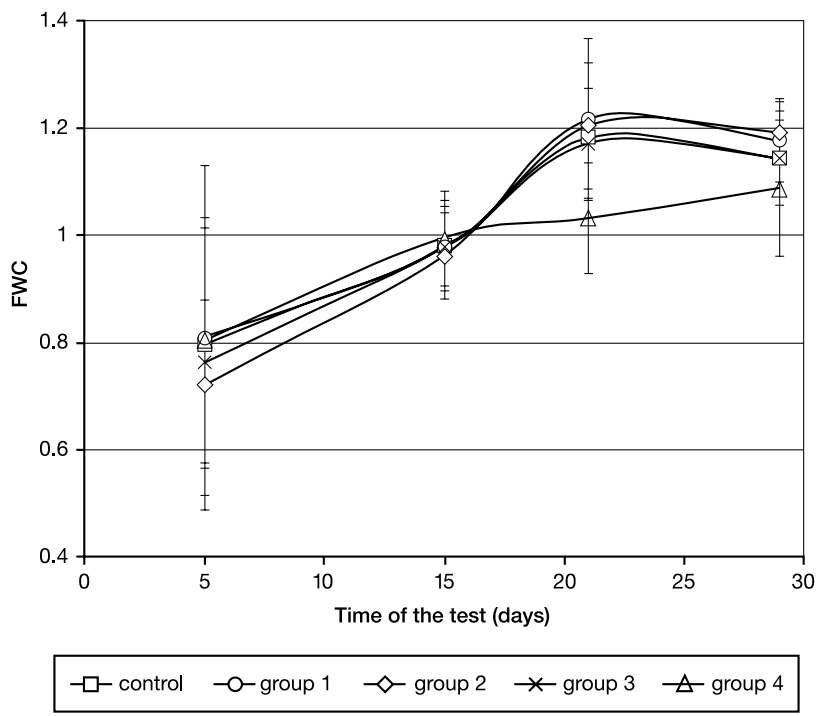

Fig 4. Fulton's weight condition factor (FWC values) of common carp larvae. Explanations: time (d) $=$ number of days after the fertilization of eggs

\section{Discussion}

The present study revealed no significant effects of DMSO at concentrations tested (0.2$5.0 \mathrm{ml} \cdot \mathrm{l}^{-1}$ ) on hatching, viability, morphology and mortality of embryos and larvae.

Bogers et al. (2006) found no negative influence on mortality, development and length growth of transgenic zebrafish (Danio rerio) in the early life stages when exposed over 
Table 2. Developmental periods and steps reached during the 29 day lasting embryo-larval test on common carp

\begin{tabular}{|l|c|c|c|c|c|}
\hline Fish Group & Control & 1 & 2 & 3 & 4 \\
\hline DMSO $\left(\mathrm{m} \cdot \cdot^{-1}\right)$ & 0 & 0.2 & 0.5 & 1.0 & 5.0 \\
\hline Sampling times & Period/step & Period/step & Period/step & Period/step & Period/step \\
\hline T5 & E8-E9 & E8-E9 & E8-E9 & E8-E9 & E8-E9 \\
\hline T15 & L4-L5 & L4-L5 & L4-L5 & L4-L5 & L4-L5 \\
\hline T21 & L4-L5 & L4-L5 & L4-L5 & L4-L5 & L4-L5 \\
\hline T29 & L5-L6 & L5-L6 & L5-L6 & L5-L6 & L5-L6 \\
\hline
\end{tabular}

a $30 \mathrm{~d}$ period to $0.1 \mathrm{ml} \cdot \mathrm{l}^{-1} \mathrm{DMSO}$. However, a significant positive effect on weight growth was observed (35\% compared to the control). Although not significantly different, a $12 \%$ higher mean weight of fish exposed to the lowest concentration $\left(0.2 \mathrm{ml} \cdot 1^{-1}\right)$ of DMSO, compared to the control group was found in the current study. Hallare et al. (2006) tested the effect of 48 and 96-h exposure of DMSO (concentration of $0.0001 \%$ DMSO (v/v) to $2.0 \%$ DMSO (v/v), e.g. $0.001 \mathrm{ml} \cdot 1^{-1}$ to $\left.20 \mathrm{ml} \cdot \mathrm{l}^{-1}\right)$ on early life stage indicators, such as egg and embryo mortality, gastrulation, somite formation, movement and tail detachment, pigmentation, heart beat, and hatching success and the levels of heat shock proteins (hsp 70 ) of zebrafish. These authors described no effect of 96-h exposure to DMSO at $20 \mathrm{ml} \cdot \mathrm{l}^{-1}$ on mortality of zebrafish embryos, with developmental defects absent at a concentration of $1 \mathrm{ml} \cdot \mathrm{l}^{-1}$, which is in accordance to our results. However, 96-h exposure of embryos to $10 \mathrm{ml} \cdot \mathrm{l}^{-1}$ DMSO in the above study caused weaker pigmentation of fish compared to the control, whereas concentrations of 15 and $20 \mathrm{ml} \cdot \mathrm{l}^{-1}$ increased the occurrence of other developmental defects and resulted in a significant reduction in the heart rate. Embryos exposed to $0.1 \mathrm{ml} \cdot \mathrm{l}^{-1}$ DMSO showed a concentration-dependent increase in hsp 70 expression. These authors recommend using DMSO as a carrier solvent in the zebrafish embryo assay at levels below $1.5 \% \mathrm{v} / \mathrm{v}\left(15 \mathrm{ml} \cdot \mathrm{l}^{-1}\right)$. However, the solvent level should be below $0.01 \% \mathrm{v} / \mathrm{v}\left(0.1 \mathrm{ml} \cdot \mathrm{l}^{-1}\right)$ DMSO according to heat shock protein analysis of the exposed embryos. Pawlowski et al. (2004ab) investigated the effects of DMSO at $0.010 \mathrm{ml} \cdot \mathrm{l}^{-1}$ on the reproduction of fathead minnow, and found no effect on both spawning and biomarker responses. However, they reported an approximately $50 \%$ reduction in the mean egg production. On the other hand, the acute toxicity of DMSO for juvenile fish is low, and values of 48 and 96hLC50 reach 10 's of $\mathrm{g} \cdot \mathrm{l}^{-1}$ (Hutchinson 2006).

The above information presented evidence that the effects of DMSO are dependent on fish species, age, type of tests used, and indicators evaluated. This is complicating the use of a mean general value for the concentration of the solvent that could be applied across different conditions.

The above data indicate that the effect of DMSO on fish organism depends on several factors (age of fish, fish species, type of test used, and indicators observed). Therefore, it is not possible to designate a safe concentration which will certainly not affect test results. It can be concluded that in case of using of DMSO as a solvent in a test, it is always necessary to include a control group with the highest DMSO concentration used to ensure that the results were not influenced by solvent itself.

\section{Raná ontogeneze, růst a mortalita kapra obecného (Cyprinus carpio) při nízkých koncentracích dimethyl sulfoxidu}

Dimethyl sulfoxid (DMSO) je důležité polární rozpouštědlo, které je méně toxické ve srovnání s ostatními rozpouštědly této kategorie. Pro své výborné vlastnosti je DMSO často používán $\mathrm{v}$ chemických reakcích k rozpouštění špatně rozpustných látek. Toto rozpouštědlo je využíváno zejména ve Filkensteinových a dalších nukleofilních substitucích. DMSO se 
také využivá v testech toxicity na vodních organismech jako pomocná látka pro rozpouštění ve vodě nerozpustných látek. V těchto případech je DMSO obvykle používán v koncentracích od 0,2 do $0,5 \mathrm{ml} \cdot 1^{-1}$. Cílem práce bylo posoudit vliv DMSO na růst, vývoj a mortalitu kapra obecného v období jeho raného vývoje. Expozice pokusných organismů byla zahájena 24 hodin po oplození jiker a trvala 29 dní, do ukončení larválního vývoje. Výsledky testu prokázaly, že žádná z testovaných koncentrací neměla vliv na mortalitu organismů, ani na výskyt abnormit. Organismy vystavené koncentracím 0,$2 ; 0,5$ a $1,0 \mathrm{ml} \cdot \mathrm{l}^{-1}$ vykazovaly také srovnatelný délkový i hmotnostní růst v porovnání s kontrolou, ale u organismů vystavených nejvyšší testované koncentraci $\left(5,0 \mathrm{ml} \cdot \mathrm{l}^{-1}\right)$ bylo zjištěno signifikantní zpomalení hmotnostního růstu ve srovnání s kontrolou (35 $\pm 9 \mathrm{mg}$, resp. $45 \pm 14 \mathrm{mg})$.

\section{Acknowledgements}

This study was supported by projects MSM6007665809, MSM6215712402 and Grant Projects of the Ministry of Agriculture of the Czech Republic No. QH 82117 and No. QH 71305. The authors gratefully acknowledge the assistance of J. Čížková and A. Kocová in conducting the laboratory tests.

\section{References}

Ball IR 1966: Toxicity of dimethyl sulphoxide to the goldfish, Carassius auratus. Nature 210: 639-640

Benville PE, Smith CE, Shanks WE 1968: Some toxic effects of dimethyl sulfoxide in salmon and trout. Toxicol Appl Pharmacol 12: 156-178

Bogers R, Mutsaerds E, Druke J, De Roode DF, Murk AJ, Van Der Burg B, Legler J 2006: Estrogenic endpoints in fish early life-stage tests: luciferase and vitellogenin induction in estrogen-responsive transgenic zebrafish. Environ Toxicol Chem 25: 241-247

Cabrita E, Robles V, Chereguini O, De Paz P, Anel L, Herraez MP 2003: Dimethyl sulfoxide influx in turbot embryos exposed to a vitrification protocol. Theriogenology 60: 463-473

Cabrita E, Robles V, Wallace JC, Sarasquete MC, Herráez MP 2006: Preliminary studies on the cryopreservation of gilthead sea bream (Sparus auratus) embryos. Aquaculture 251: 245-255

Chao NH, Chiang CP, Hsu HW, Tsai CT, Lin TT 1994: Toxicity tolerance of oyster embryos to selected cryoprotectants. Aquat Living Resour 7: 99-104

Ding FH, Xiao ZZ, Li J 2007: Preliminary studies on the vitrification of red sea bream (Pagrus major) embryos. Theriogenology 68: 702-708

Hallare A, Nagel K, Köhler HR, Triebskorn R 2006: Comparative embryotoxicity and proteotoxicity of three carrier solvents to zebrafish (Danio rerio) embryos. Ecotoxicol Environ Saf 63: 378-388

Herbold B, Haas P, Seel K, Walber U 1998: Studies on the effect of the solvents dimethylsulfoxide (DMSO) and ethylenglycoldimethylether on the mutagenity of four types of di-isocyanates in the Salmonella/microsome test. Mutat Res 412: 167-175

Hutchinson TH, Shillabeer N, Winter MJ, Pickford DB 2006: Acute and chronic effects of carrier solvents in aquatic organisms: a critical review. Aquat Toxicol 76: 69-92

Jacob SW, Bischel M, Herschler RJ 1964: Dimethylsulfoxide: Effects on the permeability of biologic membranes, preliminary report. Curr Ther Res Clin Exp 6: 193-198

Kligman AM 1965a: Topical pharmacology and toxicology of dimethyl sulfoxide-Part 1. J Amer Medica Asoc 193: 796-804

Kligman AM 1965b: Dimethylsulfoxide - part 2. J Amer Medical Assoc 193: 923-928

Kocour M, Gela D, Rodina M, Linhart O 2005: Testing of performance in common carp Cyprinus carpio L. under pond husbandry conditions I: top-crossing with Northern mirror carp. Aquac Res 36: 1207-1215

Lahnsteiner F 2008: The effect of internal and external cryoprotectants on zebrafish (Danio rerio) embryos. Theriogenology 69: 384-396

Pawlowski S, Sauer A, Shears JA, Tyler CR, Braunbeck T 2004a: Androgenic and estrogenic effects of the synthetic androgen $17 \alpha$-methyltestosterone on sexual development and reproductive performance in the fathead minnow (Pimephales promelas) determined using the gonadal recrudescence assay. Aquat Toxicol 68: 277-291

Pawlowski S, Van Aerle R, Tyler CR, Braunbeck T 2004b: Effects of 17 $\alpha$-ethinylestradiol in a fathead minnow (Pimephales promelas) gonadal recrudescence assay. Ecotoxicol Environ Saf 57: 330-345

Peňáz M, Prokeš M, Kouřil J, Hamáčková J 1983: Early development of the carp, Cyprinus carpio. Acta Sci Nat Brno 17: 1-39

Pillai BR, Rao KJ, Mohanty J 2001: Toxicity of selected cryoprotectants to the first zoeal stages of giant freshwater prawn Macrobrachium rosenbergii (de Man). Asian Fish Sci 14: 1-8

Rayburn JR, Deyoung DJ, Bantle JA, Fort DJ, Mcnew R 1991: Altered developmental toxicity caused by three carrier solvents. J Appl Toxicol 11: 253-260

Rayburn JR, Fisher WS 1997: Developmental toxicity of three carrier solvents using embryos of the grass shrimp, Palaemonetes pugio. Arch Environ Contam Toxicol 33: 217-221 
Rufli H, Fisk PR, Girling AE, King JMH, Lange R, Lejeune X, Stelter N, Stevens C, Suteau P, Tapp J, Thus J, Versteeg DJ, Niessen HJ 1998: Aquatic toxicity testing of sparingly soluble, volatile, and unstable substances and interpretation and use of data. Ecotoxicol Environ Saf 39: 72-77

Stoughton RB, Fritsch W 1964: Influence of dimethylsulfoxide (DMSO) on human percutaneous absorption. Arch Dermatol 90: 512-517

Suzuki T, Komada H, Takai R, Arii K, Kozima TT 1995: Relation between toxicity of cryoprotectant DMSO and its concentration in several fish embryos. Fish Sci 61: 193-197

Willhite CC, Katz PI 1984: Dimethylsulfoxide. J Appl Toxicol 4: 155-160

Yu ZW, Quinn PJ 1994: Dimethyl sulphoxide: A review of its applications in cell biology. Biosci Rep 14: 259-281

Zar JH 1996: Biostatistical Analysis, $3^{\text {rd }}$ ed., Prentice-Hall, New Jersey, 718 p. 